\title{
THE CARNOL PROCESS SYSTEM FOR CO2 MITIGATION AND METHANOL PRODUCTION
}

Meyer Steinberg

\section{RECEIVED}

NOV 291995

OSTI

August 14, 1995

Engineering Research and Applications Division

DEPARTMENT OF ADVANCED TECHNOLOGY

BROOKHAVEN NATIONAL LABORATORY, ASSOCIATED UNIVERSITIES, INC.

P.O. BOX 5000, UPTON, NEW YORK 11973-5000

UNITED STATES DEPARTMENT OF ENERGY

CONTRACT NO. DE-AC02-76-CH00016 


\section{DISCLAIMER}

This report was prepared as an account of work sponsored by an agency of the United States Government. Neither the United States Government nor any agency thereof, nor any of their employees, nor any of their contractors, subcontractors, or their employees, makes any warranty, express or implied, or assumes any legal liability or responsibility for the accuracy, completeness, or usefulness of any information, apparatus, product, or process disclosed, or represents that its use would not infringe privately owned rights. Reference herein to any specific commercial product, process, or service by trade name, trademark, manufacturer, or otherwise, does not necessarily constitute or imply its endorsement, recommendation, or favoring by the United States Government or any agency, contractor or subcontractor thereof. The views and opinions of authors expressed herein do not necessarily state or reflect those of the United States Government or any agency, contractor or subcontractor thereof. 


\section{THE CARNOL PROCESS SYSTEM FOR CO2 MITIGATION AND METHANOL PRODUCTION}

Meyer Steinberg

August 14, 1995

Engineering Research and Applications Division

Department of Advanced Technology

Brookhaven National Laboratory

Upton, N.Y. 11973-5000

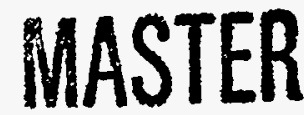

……..

DISTRIBUTION OF THIS DOCUMENT IS UNLIMTEO 


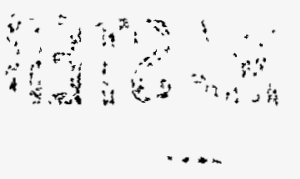




\begin{abstract}
The feasibility of an alternative $\mathrm{CO}_{2}$ mitigation system and a methanol production process is investigated. The Carnol system has three components: (1) a coal fired power plant supplying flue gas $\mathrm{CO}_{2}$ to, (2) the Carnol process which converts the $\mathrm{CO}_{2}$ with hydrogen from natural gas to methanol which is used, (3) as a fuel component in the automotive sector. For the methanol production process alone, up to $100 \% \mathrm{CO}_{2}$ emission reduction can be achieved while for the entire system up to $65 \% \mathrm{CO}_{2}$ emission reduction can be obtained. The Carnol system is technically feasible and economically competitive with alternative $\mathrm{CO}_{2}$ disposal systems for coal fired power plants. The Carnol process is estimated to be economically attractive compared to the current market price of methanol, especially if credit can be taken for the carbon as a marketable coproduct.
\end{abstract}





\section{Table of Contents}

Title

$\underline{\text { Page }}$

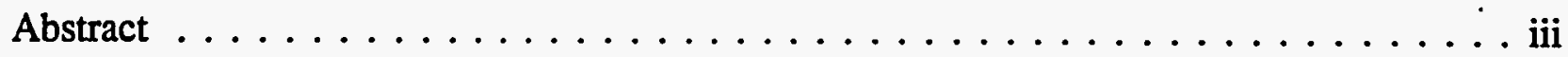

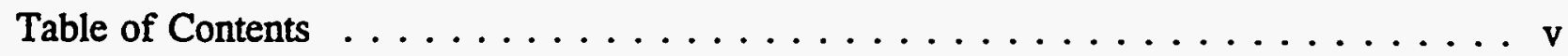

List of Figures $\ldots \ldots \ldots \ldots \ldots \ldots \ldots \ldots \ldots \ldots \ldots \ldots$

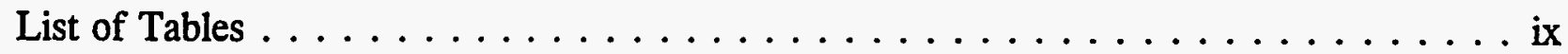

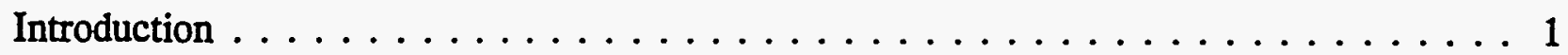

The Carnol System Configuration Development $\ldots \ldots \ldots \ldots \ldots$

Hydrogen Production with Zero $\mathrm{CO}_{2}$ Generation . . . . . . . . . . . . . . 2

The Synthesis of Methanol with Zero $\mathrm{CO}_{2}$ Emission $\ldots \ldots \ldots \ldots$

The Integrated Carnol Process System . . . . . . . . . . . . . . . 3

Preliminary Economics ...........................4

Comparison of $\mathrm{CO}_{2}$ Emission for the Carnol Process and for the Entire

Carnol System ............................. 4

Conclusions $\ldots \ldots \ldots \ldots \ldots \ldots \ldots \ldots \ldots \ldots \ldots \ldots \ldots \ldots \ldots \ldots \ldots \ldots \ldots \ldots \ldots$

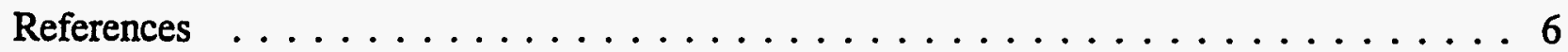




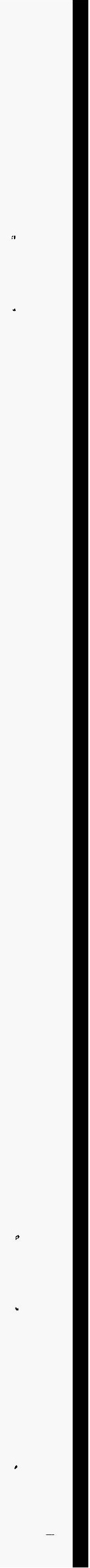




\section{List of Figures}

Figure

Page

1 Carnol System Configuration For $\mathrm{CO}_{2}$ Emission Mitigation $\ldots \ldots \ldots \ldots$

2 Carnol VI Process for $\mathrm{CO}_{2}$ Mitigation Technology $\ldots \ldots \ldots \ldots$ 


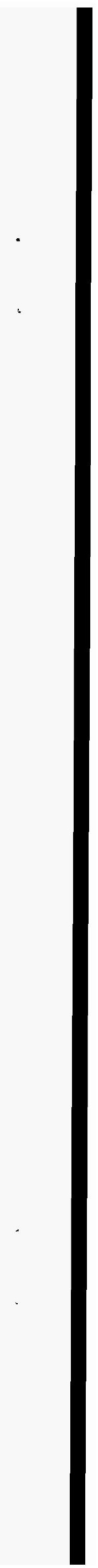




\section{List of Tables}

Table

1 Hydrogen Production - Comparison of Basic Energy Requirements and $\mathrm{CO}_{2}$ Emission $\ldots \ldots \ldots \ldots \ldots \ldots \ldots$

2 Carnol Process Design Parameters Mass and Energy Balances . . . . . . . . . 10

3 Preliminary Carnol Process Economics $\ldots \ldots \ldots \ldots \ldots \ldots \ldots$

4 Methanol Production and $\mathrm{CO}_{2}$ Emission Process Comparison . . . . . . . . 12

$5 \mathrm{CO}_{2}$ Emission From System of Coal Fired Power and Liquid HC Fueled

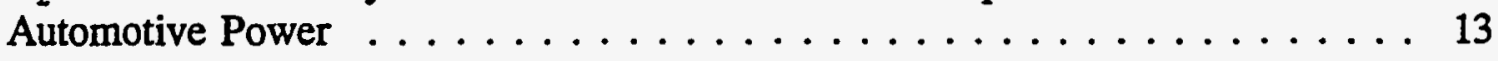




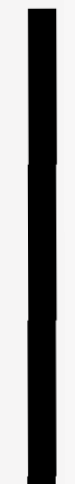




\section{The Carnol Process System for $\mathrm{CO}_{2}$ Mitigation and Methanol Production}

\section{Introduction}

The evidence for greenhouse gas $\mathrm{CO}_{2}$ warming causing global climate change is continuing to mount, and international agreements are being sought to limit $\mathrm{CO}_{2}$ emissions (Refs. 1 and 2). The $\mathrm{CO}_{2}$ emissions are primarily due to fossil fuel combustion in the commercial, industrial and transportation sectors. In the U.S. about one-third of the $\mathrm{CO}_{2}$ comes from the industrial sector mainly from central power stations which are largely fueled by coal. About an equal amount of $\mathrm{CO}_{2}$ is emitted in each of the other two sectors. In this paper we describe and develop a system, the Carnol System, which converts $\mathrm{CO}_{2}$ from coal-fired power plant stack gases with natural gas to produce methanol as a liquid fuel for use in automotive engines. Carbon is produced as a coproduct which is a storable commodity product. The carbon from the coal is used twice and, therefore, the $\mathrm{CO}_{2}$ is greatly reduced compared to conventional system.

\section{The Carnol System Configuration Development}

The basis for the Carnol system depends on integration of the following four developments.

1. A significant amount of effort and improvement has gone into the removal of $\mathrm{CO}_{2}$ from the stack gas of fossil fuel burning plants particularly for recovery and disposal of $\mathrm{CO}_{2}$ in the ocean (Refs. 3 and 4). In the Carnol configuration it is proposed to utilize the $\mathrm{CO}_{2}$ rather than dispose and sequester the $\mathrm{CO}_{2}$.

2. For purposes of providing the hydrogen to reduce the $\mathrm{CO}_{2}$ to methanol, it is proposed to thermally decompose methane (from abundant natural gas) to hydrogen and carbon. In order to produce hydrogen without generation of $\mathrm{CO}_{2}$ it is proposed not to burn the carbon produced, but to use it as a materials commodity (Ref. 5). An alternative hydrogen production process without net $\mathrm{CO}_{2}$ generation is the gasification of biomass. (wood) (Ref. 6).

3. The synthesis of methanol has been significantly improved by using liquid phase slurry catalysts (Refs. 7 and 8). It is proposed to react the $\mathrm{CO}_{2}$ saturated monoethanolamine (MEA) solvent used in the recovery of $\mathrm{CO}_{2}$ from coal-fired power plant stack gases to produce the methanol.

4. It is proposed to use the methanol produced in the Carnol system as an alternative fuel in internal combustion automotive engines in the transportation sector. It is recognized that in order to make an impact in $\mathrm{CO}_{2}$ reduction, a large market for the product methanol must be available. The automotive fuel market provides that possibility. Furthermore, it is shown that methanol is $30 \%$ more efficient in IC engines than 
conventional gasoline, thus providing further incentives for reducing $\mathrm{CO}_{2}$ emissions (Ref. 9).

Figure 1 shows a schematic of the overall Carnol configuration for achieving the $\mathrm{CO}_{2}$ emission mitigation in the industrial and transportation sectors. Each of the process operations are discussed and further developed as follows.

\section{Hydrogen Production with Zero $\mathrm{CO}_{2}$ Generation}

An investigation (Ref. 5) of the basic energy requirements and $\mathrm{CO}_{2}$ emission for various methods of hydrogen production has indicated that methane decomposition can produce hydrogen with the least $\mathrm{CO}_{2}$ emission and with the least basic energy requirements (Ref. 5). This evaluation has been extended to include steam reforming of coal and biomass in Table 1. The latter shows that only thermal decomposition of methane and the steam reforming of biomass can achieve zero $\mathrm{CO}_{2}$ emission. Of these two, the process energy requirement is the least for methane decomposition, however, the total energy requirement per unit of hydrogen is less for biomass gasification. This is so because in the thermal decomposition of methane, the carbon is not used to achieve zero $\mathrm{CO}_{2}$ emission. In biomass gasification, zero net $\mathrm{CO}_{2}$ emission is achieved because solar photosynthesis removes $\mathrm{CO}_{2}$ from the atmosphere. Although the present conventional method for hydrogen production, by steam reforming of methane, has a higher energy efficiency than the thermal decomposition of methane, it generates considerable greater amounts of $\mathrm{CO}_{2}$. Thus, thermal decomposition of methane competes with biomass gasification. From an economic point of view, natural gas, at present, is less expensive than biomass. However, a balance of not using the carbon and a lower thermal efficiency compensates somewhat for the higher cost of biomass from energy farms. Since the gasification of biomass is much better developed than the thermal decomposition of natural gas, the latter is chosen for further development.

Alternate methane decomposition reactor (MDR) designs have been considered. However, it appears that a molten metal bath which has been proposed for waste processing (Ref. 10) has a number of advantages for a MDR design. For example, bubbling methane through a bath of a low melting metal, such as tin, heated to temperatures in the order of 800 $1000^{\circ} \mathrm{C}$ could decompose over $90 \%$ of the methane. The carbon could be trapped and separated from the top of the molten metal bath due to the great density difference between carbon $(1.8 \mathrm{gm} / \mathrm{cc})$ and tin $(7.3 \mathrm{gm} / \mathrm{cc})$. The partial pressure of tin at $1000^{\circ} \mathrm{C}$ is less than $10^{-6}$ atm so that there would be no loss of tin or contamination of the hydrogen gas stream with tin. The low viscosity of tin would allow good gas/liquid contact resulting in good heat transfer between the tin and the methane gas. A reactor and process design is shown on the right hand side of Figure 2 which is based on the tin MDR reactor operating at $900^{\circ} \mathrm{C}$ and $7.5 \mathrm{~atm}$ and heat and mass balances for producing a $90 \% \mathrm{H}_{2}-10 \% \mathrm{CH}_{4}$ stream which after pressure swing absorption (PSA) produces a $100 \% \mathrm{H}_{2}$ stream. If the hydrogen is used to produce methanol, the $90 \% \mathrm{H}_{2}-10 \% \mathrm{CH}_{4}$ stream can be used directly and the PSA operation can be eliminated. 


\section{The Synthesis of Methanol with Zero $\mathrm{CO}_{2}$ Emission}

The hydrogen produced by methane decomposition is used to react with $\mathrm{CO}_{2}$ recovered from coal fired power plant.

$$
\mathrm{CO}_{2}+3 \mathrm{H}_{2}=\mathrm{CH}_{3} \mathrm{OH}+\mathrm{H}_{2} \mathrm{O}
$$

If one mole of $\mathrm{CO}_{2}$ is removed from the stack gases to produce 1 mole methanol, then when, the methanol is combusted as fuel, one mole of $\mathrm{CO}_{2}$ is produced. Therefore, the net generation of $\mathrm{CO}_{2}$ for production of methanol is zero.

Using MEA solvent gases, it is reported that it requires at least $25 \%$ of the capacity of the power plant to remove and recover $\mathrm{CO}_{2}$ from the stack gases of the power plant (Ref. 11). With improvement in absorber packing, the pressure drop for feeding flue gas through the absorber using a hindered amine solvent the fraction loss of power to recover $90 \%$ of the $\mathrm{CO}_{2}$ from a coal burning plant is reduced to $12 \%$ (Ref. 4). About $92 \%$ of the energy is needed in the stripper portion of the recovery system which is obtained from the low pressure side of the turbine and reduces the net power output of the plant. However, if the $\mathrm{CO}_{2}$ is reacted with hydrogen, methanol is produced in an exothermic reaction and that energy can be used to strip out the $\mathrm{CO}_{2}$ from the MEA and therefore it becomes unnecessary to take steam from the power plant for this purpose. Furthermore, if a liquid phase slurry catalyst system is used with an MEA solvent, the heat of reaction resulting from the synthesis of methanol is sufficient to distill out the methanol from the MEA solvent. The synthesis of methanol has an exothermic heat of reaction of $33 \mathrm{Kcal} / \mathrm{gm} \mathrm{mol} \mathrm{CO}$ (or $\mathrm{MeOH}$ ), which is more than enough to provide the heat of vaporization of methanol which is only $9 \mathrm{Kcal} / \mathrm{mol}$.

Another important point is that the equilibrium concentration of methanol produced by the reaction of $\mathrm{CO}_{2}$ with $\mathrm{H}_{2}$ is favored at lower temperatures. Equilibrium calculation indicates that the concentration of methanol at $120^{\circ} \mathrm{C}$ is 5.8 and 3.4 times that at $260^{\circ} \mathrm{C}$ for pressure of $30 \mathrm{~atm}$ and $50 \mathrm{~atm}$, respectively. The higher equilibrium methanol concentration results in a lower recycle ratio around the methanol synthesis steps and a higher thermal efficiency. The equilibrium partial pressure of $\mathrm{CO}_{2}$ can be obtained from the phase equilibrium diagram for the amine $\mathrm{H}_{2} \mathrm{O}-\mathrm{CO}_{2}$ given by Suda, et al. (Ref. 4). The liquid phase methanol slurry catalysts are under investigation by several investigators (Ref. 7). The liquid phase synthesis is favored because its heat transfer characteristics are better than the gas phase heat transfer synthesis.

\section{The Integrated Carnol Process System}

The methane decomposition molten metal reactor process can be integrated with the liquid phase synthesis of methanol, using $\mathrm{CO}_{2}$ removed from a fossil fuel fired power plant. Figure 2 shows the integrated Carnol process. A computer simulation model of the entire process has been developed to obtain material and energy balances over a range of MDR and methanol synthesis reactor (MSR) conditions. A summary of one of the computer runs of the process including the performance parameters are shown in the summary of Table 2 . The 
thermal efficiency reaches up to $50 \%$ while the total efficiency for both carbon and methanol is up to $90 \%$. The $\mathrm{CO}_{2}$ emission is reduced by $83 \%$ compared to that of the conventional methanol process based on steam reforming of natural gas.

\section{Preliminary Economics}

A preliminary estimate of the methanol production cost and $\mathrm{CO}_{2}$ credit is summarized in Table 3 for various production cost factors including natural gas and $\mathrm{CO}_{2}$ cost. The estimate is based on $90 \%$ recovery and utilization of $\mathrm{CO}_{2}$ (feed) from a $600 \mathrm{MW}(\epsilon)$ coal fired power plant. The capital investment is based on an equivalent current steam reforming plant estimated at $\$ 100,000$ per daily ton of methanol. Labor, maintenance and utilities are lumped into the fixed charge of $25 \%$ of the capital investment. At a natural gas cost of $\$ 2 / \mathrm{MSCF}, \$ 10 /$ ton storage of carbon with no income from carbon and if methanol is sold at the historic cost of $\$ 0.45 /$ gal (in the U.S.), the cost of reducing $\mathrm{CO}_{2}$ by this Carnol process amounts to $\$ 25 /$ ton $\mathrm{CO}_{2}$. At $\$ 3 / \mathrm{MSCF}$ natural gas, the cost of reducing $\mathrm{CO}_{2}$ increases to $\$ 55 /$ ton. This range of $\mathrm{CO}_{2}$ emission reduction credit is less than the maximum cost estimated for sequestering $\mathrm{CO}_{2}$ in the ocean, $\sim \$ 60 /$ ton (Ref. 11) not counting the transport of liquid $\mathrm{CO}_{2}$ from beyond $10 \mathrm{Km}$ inland from the ocean. If the carbon can be sold for $\$ 58$ to $\$ 120 /$ ton, the methanol can be produced for $\$ 0.45 / \mathrm{gal}$. However, recently due to the mandated use of methanol for MTBE oxygenation of gasoline, the price of methanol has increased to as high as $\$ 1.30 / \mathrm{gal}$ and has then dropped back to about $\$ 0.70 /$ gal. At these prices, the Carnol process can easily meet these market costs, even when charging for $\mathrm{CO}_{2}$ from the power plant at a rate of as high as $\$ 108 /$ ton. The general conclusion is that the Carnol process is potentially competitive with conventional methanol prices while significantly reducing $\mathrm{CO}_{2}$ emissions.

\section{Comparison of $\mathrm{CO}_{2}$ Emission for the Carnol Process and for the Entire Carnol System}

Since there are other competitive processes for methanol production -using alternative feedstocks, a comparison of $\mathrm{CO}_{2}$ emissions must be made between processes. Table 4 makes such a comparison. Taking the current conventional process for methanol production by steam reforming of natural gas as the base case, the Carnol process and the BCL biomass steam gasification process are compared (Ref. 6). Biomass is a feedstock of choice because it removes $\mathrm{CO}_{2}$ from the atmosphere by photosynthesis. The Carnol process obtains an $83 \%$ reduction in $\mathrm{CO}_{2}$ emission with a penalty of only $24 \%$ in production capacity of methanol when methane is used to heat the methane decomposition reactor. The $\mathrm{CO}_{2}$ emission can be eliminated in the Carnol process when hydrogen is used to heat the reactor, in which case the production capacity is reduced by $29 \%$. The steam gasification of biomass process also eliminates $\mathrm{CO}_{2}$ emission, however, a further reduction in methanol production to $35 \%$ is obtained.

While the Carnol process emission reduction can be compared on a methanol production basis as referred to above, it is necessary to estimate the $\mathrm{CO}_{2}$ emission for the entire system which includes (1) the coal-fired power plant, (2) the Carnol methanol production process and (3) the use of methanol as an automotive IC engine fuel, as shown in Figure 1. The total $\mathrm{CO}_{2}$ emission for the system, must be based consistently on the HHV of the various feedstock energy 
inputs to the system including (a) electricity from the power plant, (b) liquid methanol fuel from the Carnol plant and (c) mechanical energy from the automotive IC engines. This was done in Table 7 for 4 systems: 1) current conventional coal fired power plant, and gasoline driven automobiles; 2) coal fired power plant with conventional natural gas steam reforming for methanol production and methanol fueled vehicles; 3 ) coal-fired power plant with Carnol process for methanol production and use of methanol fueled vehicles, and 4) coal-fired power plant with biomass gasification methanol production and with methanol fueled vehicles. Several assumptions must be made for a valid comparison.

- The oil refinery produces gasoline at $90 \%$ efficiency; the equivalent of $10 \% \mathrm{C}$ is lost as $\mathrm{CO}_{2}$.

- The thermal efficiency for steam reforming of methane to methanol is $64 \%$.

- The Carnol thermal efficiency is $90 \%$.

- The net $\mathrm{CO}_{2}$ emission based on biomass gasification is zero.

- The methanol fueled vehicle is $30 \%$ more efficient than gasoline driven vehicle (Ref. 9).

The results shown in Table 5 indicate that the $\mathrm{CO}_{2}$ emission reduction is reduced by $18 \%$ using conventional steam reforming of natural gas for methanol production and its use in vehicles. The $\mathrm{CO}_{2}$ is reduced by $63 \%$ for the Carnol methanol process and $65 \%$ reduction when biomass gasification is used. The latter two thus achieves significant reductions in $\mathrm{CO}_{2}$ emission for the entire system. From an economic point of view, the biomass feedstock is currently more expensive than natural gas in the U.S. and, therefore, for about equal $\mathrm{CO}_{2}$ emission reduction, the Carnol natural gas process presently should be more economical.

\section{Conclusions}

The Carnol process system configuration appears to be technically feasible and economically viable both as a $\mathrm{CO}_{2}$ mitigation method for coal-fired power plants and as a methanol production process compared to the conventional method especially when considering credit for marketing the carbon coproduct. For process improvement, the development of a molten metal methane decomposition reactor and a $\mathrm{CO}_{2}$ liquid phase catalytic slurry methanol synthesis reactor are recommended. 


\section{References}

1. Stevens, W.K., "Scientists Warn of Effect of Rise in Greenhouse Gases," New York Times, The Environment, p. C4, April 11, 1995.

2. Mills, E., D. Wilson, and T. Johansson, "Getting Started. No Regrets Strategies for Reducing Greenhouse Gas Emissions," Energy Policy, July/August 1991.

3. U.S. Department of Energy, "The Capture Utilization and Disposal of $\mathrm{CO}_{2}$ from Fossil Fuel-Fired Power Plants," Vols. I and II, Washington, D.C., 1993.

4. Suda, T., et al., "Development of Fuel Gas Carbon Dioxide Recovery Technology," Chapter in Carbon Dioxide Chemistry: Environment Issues, Ed. By Jon Paul and ClaireMarie Pradier, The Royal Society of Chemistry, 1994 and private communication, p. 222-35, June 1995.

5. Steinberg, M., "The Hy-C Process (Thermal Decomposition of Natural Gas) Potentially the Lowest Cost Source of Hydrogen with the Least $\mathrm{CO}_{2}$ Emission," BNL-61364, Brookhaven National Laboratory, Upton, N.Y., December 1994.

6. Larson E.O., and R.E. Katofsky, "Production of Hydrogen and Methanol via Biomass Gasification," in Advances in Thermochemical Conversion, Elsevier Applied Science, London, 1992.

7. Lee, S., Methanol Synthesis Technology, CRC Press, Inc., Boca Raton, Florida, p. 198224, 1990.

8. Okyama, S., "Evaluation of Low Temperature Methanol Synthesis in the Liquid Phase," ACS Division of Fuel Chemistry, $200^{\text {th }}$ ACS National Meeting 39 No. 4, Washington, D.C., p. 1182-6, August 20-25, 1994.

9. EPA Report, "An Analysis of the Economic and Environmental Effects of Methanol as an Automotive Fuel," EPA Report No. 0730, Motor Vehicle Emissions Laboratory, Ann Arbor, Michigan, September, 1989.

10. Nahass, P., P.A. Moise and C.A. Chanenchuk, "Quantum CEP for Mixed Waste Processing," Molten Metal Technology, Inc., Waltham, Mass., 1994.

11. IEA Greenhouse Gas R and D Programme Report "Carbon Dioxide Capture From Power Stations," Cheltenham, U.K., 1994. 
Figure 1

\section{CARNOL System Configuration For $\mathrm{CO}_{2}$ Emission Mitigation}

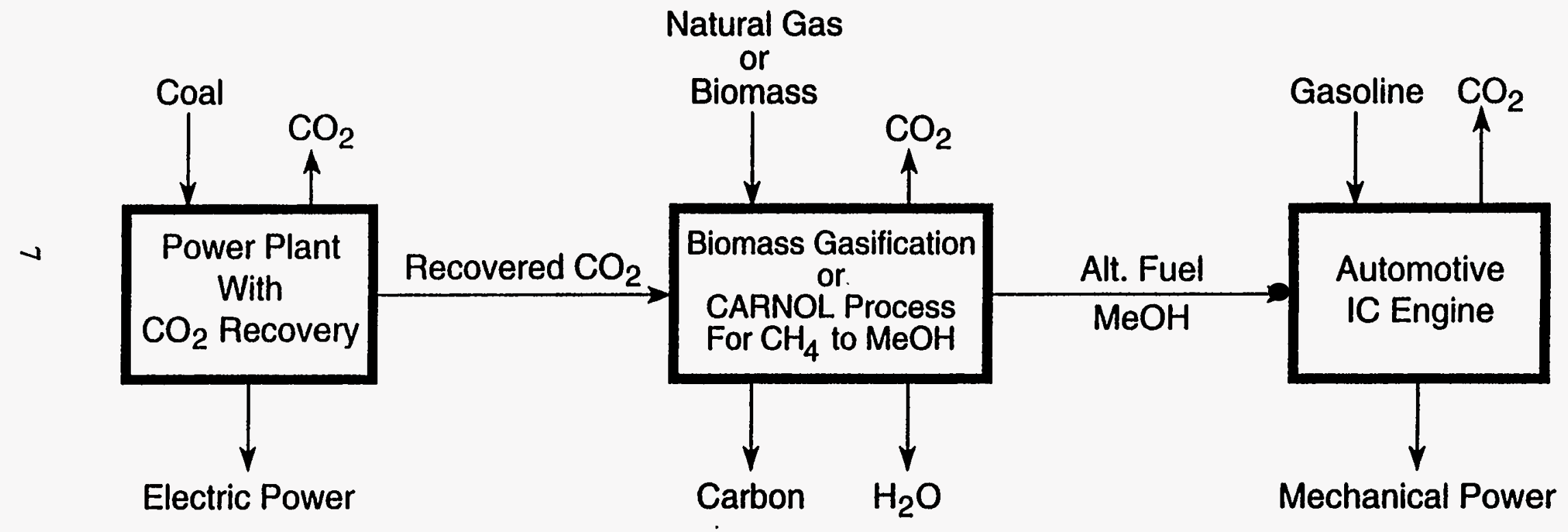


Figure 2

\section{Carnol VI Process for $\mathrm{CO}_{2}$ Mitigation Technology}

Combining $\mathrm{CO}_{2}$ Recovery From Power Plants With Liquid Metal Methane Decomposition and Liquid Phase Methanol Synthesis

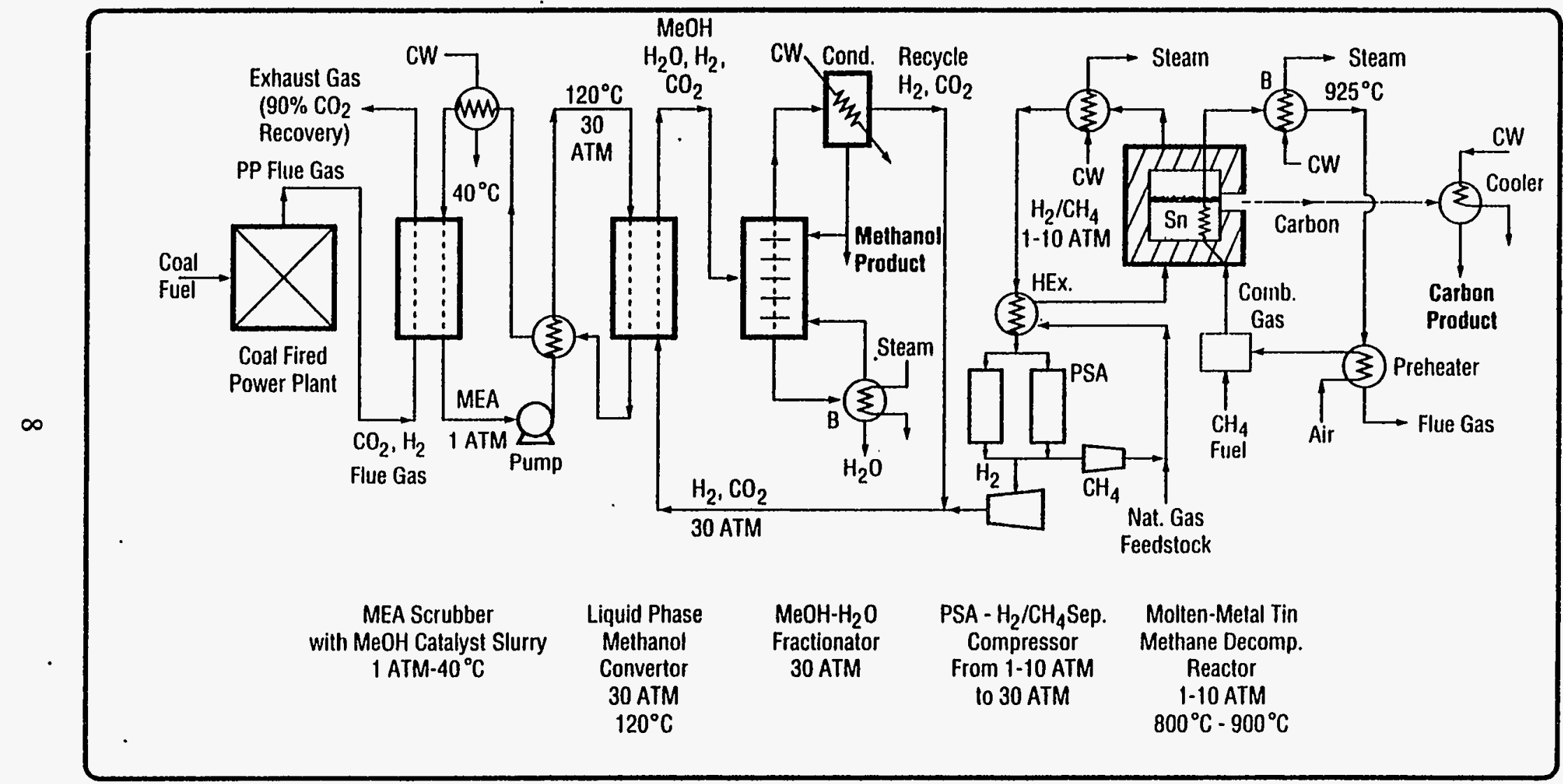

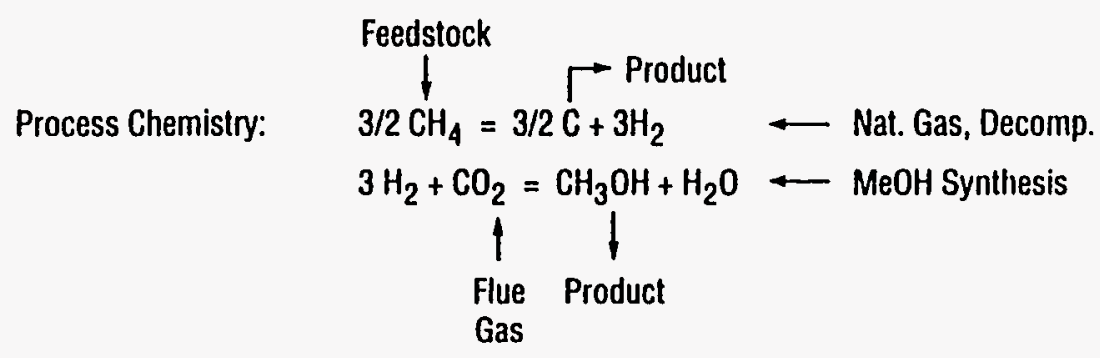




\begin{tabular}{|c|c|c|c|c|c|c|c|c|}
\hline \multirow{3}{*}{ PROCESS } & \multicolumn{7}{|c|}{$\begin{array}{c}\text { TABLE 1 } \\
\text { HYDROGEN PRODUCTION } \\
\text { Comparison of Basic Energy Requirements and } \mathrm{CO}_{2} \text { Emission }\end{array}$} & \multirow{3}{*}{$\begin{array}{c}\mathrm{CO}_{2} \\
\text { EMISSION } \\
\frac{\mathrm{mol} \mathrm{CO}}{\mathrm{mol} \mathrm{H}_{2}}\end{array}$} \\
\hline & \multicolumn{2}{|c|}{ ENERGY EFFICIENCY } & \multirow{2}{*}{$\begin{array}{l}\text { PROCESS } \\
\text { FUEL }\end{array}$} & \multirow[t]{2}{*}{ FEEDSTOCK } & \multirow{2}{*}{$\begin{array}{l}\text { RATIO } \\
\frac{\mathrm{mol} \mathrm{H}_{2}}{\mathrm{~mol} \mathrm{CH}}\end{array}$} & \multicolumn{2}{|c|}{$\begin{array}{c}\text { ENERGY-Kcal/mol } \\
\mathrm{H}_{2}\end{array}$} & \\
\hline & $\begin{array}{l}\text { Process } \\
\text { Energy }\end{array}$ & $\begin{array}{l}\text { Overall } \\
\text { Fuel }\end{array}$ & & & & Process & Total & \\
\hline $\begin{array}{l}\text { 1. METHANE THERMAL } \\
\text { DECOMPOSITION } \\
\mathrm{CH}_{4}=\mathrm{C}+2 \mathrm{H}_{2}\end{array}$ & $\begin{array}{l}\text { (A) } 80 \%(t) \\
\text { (B) } 80 \%(t) \\
\text { (C) } 80 \%(t)\end{array}$ & $\begin{array}{l}53.3 \%(t) \\
58.1 \%(t) \\
64.2 \%(t)\end{array}$ & $\underset{\mathrm{C}}{\mathrm{CH}_{2}}$ & $\begin{array}{l}\mathrm{CH}_{4} \\
\mathrm{CH}_{4} \\
\mathrm{CH}_{4}\end{array}$ & $\begin{array}{l}1.67 \\
1.81 \\
2.00\end{array}$ & $\begin{array}{l}11.3 \\
11.3 \\
11.3\end{array}$ & $\begin{array}{l}126.9 \\
117.1 \\
106.0\end{array}$ & $\begin{array}{l}0.00 \\
0.05 \\
0.12\end{array}$ \\
\hline $\begin{array}{l}\text { COMBINED CYCLE } \\
\text { POWER FOR } \\
\text { ELECTRICAL HEATING }\end{array}$ & (D) $\begin{array}{l}55 \%(t) \\
\frac{80 \%(t)}{44 \%(t)}\end{array}$ & $53.9 \%(t)$ & $\mathrm{CH}_{4}$ & $\mathrm{CH}_{4}$ & 1.68 & 11.3 & 126.2 & 0.10 \\
\hline $\begin{array}{l}\text { 2. METHANE STEAM } \\
\text { REFORMING } \\
\mathrm{CH}_{4}+2 \mathrm{H}_{2} \mathrm{O}=\mathrm{CO}_{2}+4 \mathrm{H}_{2} \\
\end{array}$ & $80 \%(t)$ & $94.6 \%(t)$ & $\mathrm{CH}_{4}$ & $\mathrm{CH} 4+\mathrm{H}_{2} \mathrm{O}$ & 2.95 & 18.8 & 71.9 & 0.34 \\
\hline $\begin{array}{l}\text { 3. COAL STEAM } \\
\text { REFORMING } \\
\text { CO } \mathrm{O}_{0.3} \mathrm{O}_{0.0 \mathrm{Oe}}+1.92 \mathrm{H}_{2} \mathrm{O}=\mathrm{CO}_{2} \\
+2.32 \mathrm{H}_{2}\end{array}$ & $80 \%(t)$ & $92.4 \%(t)$ & COAL & $\mathrm{COAL}+\mathrm{H}_{2} \mathrm{O}$ & $\begin{array}{l}1.45 \\
H_{2} / \text { Coal }\end{array}$ & 21.8 & 73.5 & 0.69 \\
\hline $\begin{array}{l}\text { 4. BIOMASS STEAM } \\
\text { REFORMING } \\
\mathrm{CH}_{1.6} \mathrm{O}_{0.0}+1.4 \mathrm{H}_{2} \mathrm{O}= \\
\mathrm{CO}_{2}+2.15 \mathrm{H}_{2}\end{array}$ & $80 \%(t)$ & $92.0 \%(t)$ & BIOMASS & $\underset{\mathrm{H}_{2} \mathrm{O}}{\text { BIOMASS + }}$ & $\begin{array}{c}1.54 \\
\mathrm{H}_{2} / \text { Blomass }\end{array}$ & 20.3 & 73.9 & 0.00 \\
\hline
\end{tabular}




\section{Table 2 \\ Carnol Process Design Parameters \\ Mass and Energy Balances}

\begin{tabular}{|c|c|}
\hline \multicolumn{2}{|l|}{ MDR } \\
\hline Pressure, atm & 7.5 \\
\hline Temperature, ${ }^{\circ} \mathrm{C}$ & 900 \\
\hline \multicolumn{2}{|l|}{ MSR } \\
\hline Pressure, atm & 30 \\
\hline Temperature, ${ }^{\circ} \mathrm{C}$ & 120 \\
\hline \multicolumn{2}{|l|}{ PERFORMANCE } \\
\hline Ratio, Methanol $/ \mathrm{CH}_{4}, \mathrm{~kg} / \mathrm{kg}$ & 1.19 \\
\hline Ratio Carbon/Methanol, kg/kg & 0.57 \\
\hline Thermal Efficiency of MeOH, & $49.7 \%$ \\
\hline Total Thermal Efficiency, $\mathrm{C}+\mathrm{MeOH}$ & $89.7 \%$ \\
\hline $\mathrm{CO}_{2}$ Emissions, $\mathrm{lb} \mathrm{CO}_{2} / \mathrm{MMBTU}$ & 30.2 \\
\hline $\mathrm{kg} \mathrm{CO}_{2} / \mathrm{GJ}$ & 13.0 \\
\hline $\begin{array}{l}\mathrm{CO}_{2} \text { Emission Reduction Compared to } \\
\text { Conventional Steam Reforming Process }\end{array}$ & $83.4 \%$ \\
\hline
\end{tabular}


E

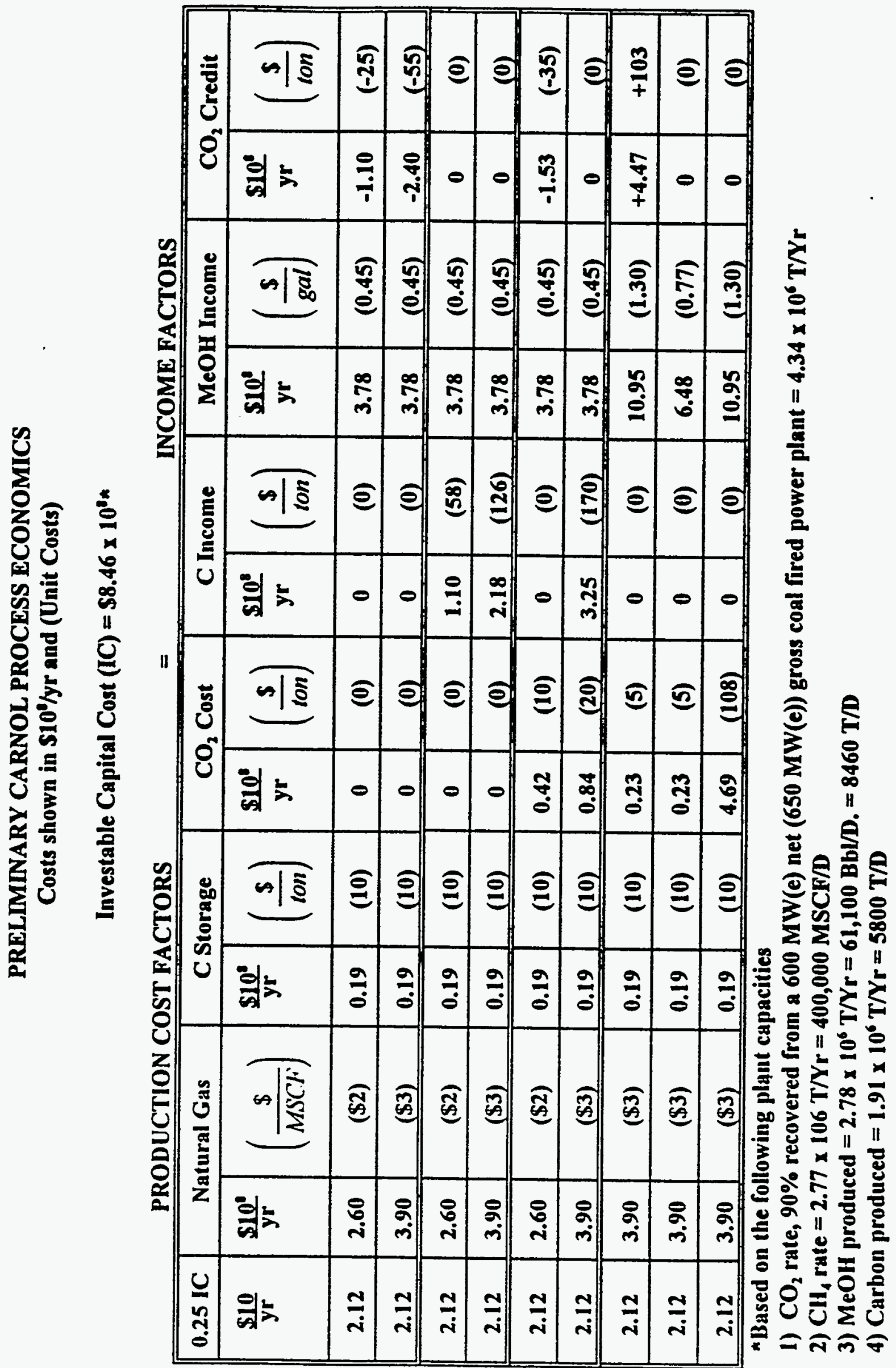


Table 4

\section{Methanol Production and $\mathrm{CO}_{2}$ Emission Process Comparison}

\begin{tabular}{|c|c|c|c|c|}
\hline \multirow{2}{*}{ PROCESS } & \multicolumn{2}{|c|}{ PRODUCTION CAPACITY } & \multicolumn{2}{|c|}{$\mathrm{CO}_{2}$ EMISSION } \\
\hline & $\begin{array}{c}\text { Moles MeQH } \\
\text { Moles } \\
\text { Feedstock }\end{array}$ & $\begin{array}{l}\text { \% Reduction from } \\
\text { Conventional }\end{array}$ & $\frac{\text { lbs CO }}{\text { MMBTU }}$ & $\begin{array}{l}\text { \% Reduction from } \\
\text { Conventional }\end{array}$ \\
\hline $\begin{array}{l}\text { Conventional Process } \\
\text { Steam Reforming of } \mathrm{CH}_{4}\end{array}$ & 0.76 & $0 \%$ & 180 & $0 \%$ \\
\hline $\begin{array}{l}\text { Carnol Process } \\
\text { from } \mathrm{CH}_{4} \text { (and } \mathrm{CO}_{2} \text { ) }\end{array}$ & $\begin{array}{l}0.58^{14} \\
0.54^{(2)}\end{array}$ & $\begin{array}{l}24 \% \\
29 \%\end{array}$ & $\begin{array}{r}30 \\
0\end{array}$ & $\begin{array}{r}83 \% \\
100 \%\end{array}$ \\
\hline $\begin{array}{l}\text { Steam Gasification } \\
\text { of Biomass }\end{array}$ & 0.50 & $35 \%$ & $\mathbf{0}$ & $100 \%$ \\
\hline
\end{tabular}

(1) Heating methane decomposition reactor with $\mathrm{CH}_{4}$.

(2) Heating methane decomposition reactor with $\mathrm{H}_{2}$. 
TABLE 5

$\mathrm{CO}_{2}$ EMISSION FROM SYSTEM OF COAL FIRED POWER AND LIQUID HC FUELED AUTOMOTIVE POWER

\begin{tabular}{|c|c|c|c|}
\hline \multicolumn{4}{|c|}{$\begin{array}{l}\text { Emission Units in Lbs/MMBTU (HHV) } \\
\text { (Multiply by } 0.43 \text { to Convert to Kg/GJ) }\end{array}$} \\
\hline SYSTEM & $\begin{array}{l}\text { UNIT } \mathrm{CO}_{2} \\
\text { EMISSION }\end{array}$ & $\begin{array}{l}\mathrm{CO}_{2} \text { EMISSION FROM } \\
\text { COMBINED SYSTEM }\end{array}$ & $\begin{array}{l}\% \mathrm{CO}_{2} \text { EMISSION } \\
\text { REDUCTION FROM } \\
\text { CURRENT SYSTEM } \\
\end{array}$ \\
\hline $\begin{array}{l}\text { COAL FIRED POWER PLANT } \\
\text { Gasoline' Fueled Automotive IC Engine } \\
\text { (Current System) }\end{array}$ & $\begin{array}{l}215 \\
196\end{array}$ & 205 & $0 \%$ \\
\hline $\begin{array}{l}\text { COAL FIRED POWER PLANT } \\
\text { Natural Gas to Methanol } \\
\text { by Conventional Reforming and with } \\
\text { Methanol Fueled Automotive IC Engine }\end{array}$ & $\begin{array}{r}215 \\
139\end{array}$ & 169 & $18 \%$ \\
\hline $\begin{array}{l}\text { COAL FIRED POWER PLANT } \\
\text { Carnol MeOH Plant (Methane Decomp) } \\
\text { Plant with Methanol Fueled Automotive } \\
\text { IC Engine }\end{array}$ & 215 & 76 & $63 \%$ \\
\hline $\begin{array}{l}\text { COAL FIRED POWER PLANT } \\
\text { Biomass MeOH } \text { (Gasification) Plant with }^{4} \\
\text { Methanol Fueled Automotive IC Engine }\end{array}$ & $\begin{array}{l}215 \\
106\end{array}$ & 71 & $65 \%$ \\
\hline
\end{tabular}




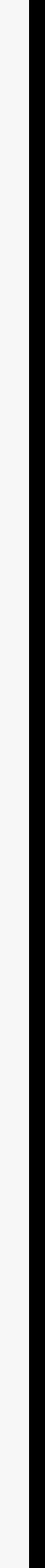

